\title{
A Study on Applying the Variation Theory to \\ Chinese Communicative Writing
}

\author{
Mei-yi Cheng \\ Hong Kong Institute of Educational Research, the Chinese University of Hong Kong \\ Shatin, New Territories, Hong Kong \\ Tel: 852-2948-3257Ｅ-mail: nataliecheng@cuhk.edu.hk
}

Chi-ming Ho

Centre for Assessment Research and Development, the Hong Kong Institute of Education

Rm. 8, 2/F., Block B1, 10 Lo Ping Road, Tai Po, New Territories, Hong Kong

Tel: 852-2948-8558Ｅ-mail: cmh@ied.edu.hk

\begin{abstract}
This study attempted to apply the variation theory to teach Chinese communicative writing. The aim of the study was to exhibit the students' capability of experiencing the phenomena in different ways and so showed qualitative difference in their approach to writing. It was hoped that the result would shed a new light on reducing the problem of students' writing in monotonous ways and lack of focus in the future. 38 students in a Primary 5 class took part in the study. Three learning tasks were designed and systematically structured to help to facilitate students' discernment of the critical features of Chinese communicative writing, i.e., the communicative purpose, communicative targets and communicative messages. A comparison between students' writings before and after the study revealed qualitative difference in their writings. In the post-study writing, students showed clearer purpose of communication.
\end{abstract}

Keywords: Chinese communicative writing, Variation theory, Chinese subject teaching, Primary education

\section{Background}

The teaching of writing is one of the main concerns of teachers or educators. Being able to write proficiently seems to make evident of being having high language abilities. Indeed, writing has pragmatic value for people in their daily life. As Grabe and Kaplan (1996) pointed out, people engaged in different kinds of writing in the everyday world whereas these varieties "represent the ability to control the written medium of language to some extent" (p.3). Thus, it is the responsibility of teachers to help their students equipped with appropriate writing abilities for daily and future use.

Learning means to experience the phenomena and be able to discern its critical aspects (Marton \& Booth, 2003). In addition to experiencing various use of language, students should be enabled to enrich their learning. As Marton, Runesson and Tsui (2004) said, "how the learning experience is being constituted by language is crucial to understanding how different ways of experiencing the object of learning are being brought about in the classroom" (p.25). Writing is a means for students to express what they see, hear, perceive, think, understand and conceptualize something in their experience in written form. Because they will experience the phenomena in different ways, what they write should also be different. However, the writings of Hong Kong students are always criticized as lacking of focus and expressing in monotonous ways. Something might be going wrong and it should be found out in order to solve the students' problem in writing.

Some teachers attributed the unsatisfactory performance to students' being unmotivated to write. Other teachers thought that the situation was due to students' being unable to grasp the writing strategies. As a result, various pedagogies have been used in the hope of improving students' motivation and writing skills. This seems to have effects on students' writing as motivation and writing strategies are essential for their learning to write. Writing motivation is important as we should have a fair understanding of what students "are expected to learn in particular situation" (Marton, Runesson \& Tsui, 2004, p.3). However, it cannot ensure that the effects are stable or lasting. In other words, students who have learnt writing strategies might still be unable to transfer these skills in other situation. They may only mechanically display various skills in their writing. It is because they learn writing strategies without authentic experience as well as communicative targets and purposes. If students lack the opportunity of learning to experience the various phenomena, 
they will be unable to discern the critical aspects which are essential for relating a learning experience to others (Marton $\&$ Booth, 1997). In other words, students need to experience diverse phenomena in order to discern the critical features of language usage. Consequently, they can use appropriate language to meet the demand of different contexts in their daily life. Furthermore, it cannot be claimed that various pedagogies are critical therapy for students' problem in writing. Pedagogy still signifies much stress on the teaching acts rather than the learning acts. With reference to these ideas, this study attempted to apply the variation theory to teach Chinese communicative writing.

\section{Variation theory and Chinese communicative writing}

\subsection{Variation theory}

The variation theory of learning was developed by Marton and Booth (1997). It "is not a theory of the mechanisms of learning but a theory of the relation between the object of learning and the learner" (Runesson (2006, p.406). The object of learning is broadly regarded as "the complex of different ways of experiencing the phenomenon to be learned about" (Marton \& Booth, 1997, 162). Specifically, it may mean the capability of do something with something (Marton, Runesson, \& Tsui, 2004). To learn means to experience while to experience means to be aware of certain aspects in a given context and relate them to this context. Discernment of these aspects varies and comes to the forefront of focus simultaneously as a result of different ways of experiencing by individuals. Moreover, only experiencing variation, which is a decisive condition for learning, can evoke discernment of these aspects. However, not all the aspects are significant for learning. A critical aspect of the object of learning contributes to a particular meaning in the learner's awareness. Only variation in the critical aspects is an essential condition for learning (Holmqvist, Gustavsson \& Wernberg, 2007; Runesson, 2006; Wood, 2006).

There are four patterns of variation which can facilitate students' discernment of critical features or aspects of the object of learning. They are "contrast", "generalization", "separation" and "fusion" (Marton, Runesson \& Tsui, 2004):

Contrast. Experience something else to compare it with.

Generalization. Experience varying appearance of an object.

Separation. Experience a certain aspect of something by means of varying it while other aspects remain invariant.

Fusion. Experience several critical aspects simultaneously.

In this study, the patterns of "separation" and "fusion" would be used.

\subsection{Chinese communicative writing}

When adopting a communicative approach to writing, an emphasis is placed on developing a sense of audience to whom the messages of writing are conveyed. Factors facilitating or blocking the delivery of messages in the writing will be identified in order to enable the writers to communicate their writing messages to their communicative targets in more effective ways. These factors should be considered before and during writing. They include the status of writer, the status of reader, communicative intonation, communicative structure, communicative format, communicative agreement, communicative medium, communicative purpose, communicative objective and communicative context. Being able to discern these factors and make use of them in the writing will be considered as acquiring communicative writing ability. This ability should be part of the writing abilities that children should develop (Tse, 2002).

Each communicative target or each group of communicative targets is unique. It is supposed that the communicative messages should be different in response to diverse demand or expectation of various communicative targets or groups of communicative targets. These ideas are in coincidence with some objectives of the National Assessment of Educational Progress (NAEP) that students should "write for a variety purposes", "write on a variety of tasks and for many different audiences", "display effective choices in the organization of their writing", and "value writing as a communicative activity" (the National Assessment Governing Board, 1998, p.5). The awareness of the writing purpose, the audience and the task itself are essential in writing assessment while the audience is particular central to the scoring of the NAEP (Wolcott \& Legg, 1998). Theoretically, students' writing should not be expressed in monotonous ways and lacking of focus if they have developed the sense of communicative targets, i.e. the audience. In short, the capability in communicative writing should be regarded as a benchmark on writing ability. This study intended to apply this notion to Chinese writing together with the idea of variation theory.

\subsection{Object of learning and critical features in this study}

When applying the variation theory, the development of students' capability in Chinese communicative writing is the object of learning while all these elements or factors are critical features in the writing phenomena. An authentic learning context can be structured so that students are given opportunities to experience and discern these critical aspects. Various communicative elements or factors can be embedded in the same writing scenario or one of them can be placed in various writing scenarios. This can enable students to separate these critical features which are essential for their development of communicative writing abilities. A writing task can also be designed so that students have to 
experience communicative elements or factors simultaneously. However, it is difficult for students to discern all the communicative elements at the beginning of learning. It would be a great burden on them. Indeed, "only a limited number of aspects can be discerned and focused on at the same time" (Holmqvist, Gustavsson \& Wernberg, 2007, p.183). With reference to teaching experience, the teacher who participated in this study expressed that her students seemed to regards writing as a homework assigned by her. The purpose of writing was to fulfill her expectation and the communicative target was only her. Thus, her students' writings always expressed in monotonous ways and were lacking of focus. The situation seems to be popular in Hong Kong. After discussion with the teacher, it came to an agreement that helping students to develop a sense of authentic communicative purpose, target and relevant messages in their writing was in an immediate need.

In this study, the development of students' capability in Chinese communicative writing should become the objects of learning in the writing phenomena whereas the communicative purpose, communicative targets and communicative messages were the critical features. A pattern of variation and invariance that served the function of "separation" and "fusion" was developed to show students that different communicative approach and messages with clear and definite communicative purpose would be used for different communicative targets; first to have students discussed and defined the communicative purpose of tasks, and expressed the different lines of thinking in accordance with the difference in the communicative targets of communication; then to discuss the background information of different communicative targets and the importance of selecting communicative materials relevant for the communicative targets. In short, three critical features designed for students' discernment in this study were listed as below:

Given the same communicative purpose, the content of communicative messages should be in match with the communicative target.

Given the same communicative target and the communicative purpose, the content of communicative messages should be in match with the communicative purpose.

The content of communicative messages was relative to the communicative purpose and the communicative target.

\section{Research design and methods}

The study adopted a phenomenographic approach "in which the focus is on describing the qualitatively different ways people approach and perceive particular tasks in relation to particular" (Prosser, 1994, p.31). 38 students in a Primary 5 class of a local school in Hong Kong took part in the study.

\subsection{Design of lesson}

In the study, the patterns of variation and invariance in the object of learning and its associated critical features were identified from students' different ways of understanding of the object of learning. A teaching plan of a double lesson was designed to help to facilitate students' discernment of the critical features of Chinese communicative writing, i.e., the communicative purpose, communicative targets and communicative messages. It was unrealistic to think that the students' writing would be significantly improved after 2 lessons of learning. However, the study tried to exhibit the students' capability of experiencing the phenomena in different ways and so showed qualitative difference in their approach to writing. As Bowden (1994) points out, "teaching should not be viewed simply as an activity by the teacher per se but rather as an activity focused on enabling learners to make changes in their own thinking" (p.43). The result of this study, in our hope, would shed a new light on reducing the problem of students' writing in monotonous ways and lack of focus in the future.

A double lesson was planned for the implement of the intervention. Three learning tasks were designed and systematically structured to help to facilitate students' discernment of the critical features. A particular context was introduced in each learning task as "our experiences of anything are always embedded in a context" (Marton \& Booth, 1997, p.96). In each task, a pattern of variation and invariance that serves the function of "separation" or "fusion" was developed to show students that different communicative approaches and messages with clear and definite communicative purpose would be used for different communicative targets.

\section{(1) Learning Task 1}

Context: It is very hot. You have just done exercise in a playground and feel very thirsty. You want to buy a soft drink stored in an auto-selling machine. But you find that you have a ten dollar money note and do not have any coins. You have to ask someone to give you change.

Task: There are four cards represented different persons. They are a friendly classmate, a ferocious stranger, a severe teacher and a naïve child. A student is asked to take one of the cards randomly and find out whom he/she will ask for a change of coins. He/she should consider the background information of the person and use suitable oral language to persuade him/her to give change. After he/she has finished his/her task, another student will come out, take another card, and does the task. When the student does the task, other students should observe how he/she attempts to achieve his/her mission. Afterwards, the teacher conducts a discussion among the students. 
Critical feature: Given the same communicative purpose, the content of communicative messages should be in match with the communicative target.

The pattern of variation and invariance: Separation

(2) Learning Task 2

Context: One day, you meet young Edison who is nine years old. You want him to be your friend.

Task: At the beginning, the students read the information about young Edison. Then they form a group in four and are given ten items of speech which will be used to talk to Edison. They should consider the background information of Edison. They have to discuss and choose 3 items of which they think the messages will arouse the interest of Edison and so he is willing to make friends with them. Then they will share their thinking with other groups. Afterwards, the teacher conducts a discussion among the students.

Critical feature: Given the same communicative target, the content of communicative messages should be in match with the communicative purpose.

The pattern of variation and invariance: Separation

\section{(3) Learning Task 3}

Context: There are a number of people who have made contribution to Hong Kong. You really admire one of them. You want to have a date with him/her so that you can be more acquainted with him/her. You also want to learn from him/her. There is also a little child who is so sweet that you want to have a date with him.

Task: At the beginning, the students read the information about the people. The people include the Prime Minister of China, the Chief Executive of Hong Kong, a famous athlete and a popular singer. Besides, there is a little child who is lovely and the students may also want to have a date with him. The students will form a group in four. They will discuss and decide with whom they want to have a date. The students will write a letter to invite one of them. They should consider the background information of the person and decide what the content of letter is about. Then they will share their thinking with other groups. Afterwards, the teacher conducts a discussion among the students.

Critical feature: The content of communicative messages is relative to the communicative purpose and the communicative target which should be in match with each other.

The pattern of variation and invariance: Fusion

\subsection{Pre-writing and post-writing}

A writing task was designed for pretest and posttest. In the writing task, the students were asked to play the role of a junior tour guide in an ocean aquarium. Their responsibility was to introduce marine animal to the tourists. As Barone and Taylor (2007) said, "forms of writing used in writing assessment often are based on the purpose of the writing prompt" which can be provided texts or informational texts in expository writing (p.25). The students were provided a list of information about the whale. The writing task required them to choose among the information and write a pamphlet. Four tourists represented different roles would visit to the aquarium. They were a Primary 2 student, a teacher who taught the subject of history, a biologist and a green sweater worker. The students, being in the role of a tour guide, could choose one of the tourists and introduced the whale with reference to what they have written in the pamphlet. If the tourist was satisfactory with their performance, they could promote to the post of senior tour guide. Thus, they had a clear and definite communicative purpose in their writing. Their main challenge was to write the pamphlet in which the information of the whale should be able to arouse the interest of their particular customer. In other words, the content of communicative messages was relative to the communicative target as well as the communicative purpose.

Both pretest and posttest writing were the same. The students had to finish their writing within 40 minutes in school. The same researchers would read the students' writing without any indication of their names in a separate setting. The procedures of encoding the writing were the same. They would summarize the messages in every paragraph of the students' writing and sorted them into categories. Then they would compare their messages and categories to see whether they were matched. If there was any disagreement, they would read the writing again and tried to reach a compromise. Afterwards, they would encode the messages and categories and try to find out whether there were patterns of variation appeared in the students' writing.

The study would try to find out whether there was qualitative difference in the students' approach to the writing task before and after the intervention. As the objectives of Chinese communicative writing were similar to those of NAEP's writing assessment, the analysis of this study was based on its ideas of primary trait scoring. Whereas the communicative purpose, communicative targets and communicative messages were the critical features in this study, the traits included "audience and purpose", "details", and "organization" would be taken into consideration in the analysis. Furthermore, the scoring rubrics for the $4^{\text {th }}$ grade students would be the references to the analysis because the grade level was near the age of the students. The descriptions of the advanced achievement level of these three traits in the $4^{\text {th }}$ 
grade of the NAEP were as follows:

Audience and purpose: Demonstrates effective, well-developed response based on allowable time limits; shows clear understanding of the writing task and the expected audience;

Details: includes details and elaboration that support main idea;

Organization: Is clearly organized, using consistency of topic of theme, sequencing or clearly marked beginning and ending (Barone \& Taylor, 2007, p.20).

With regards to the above trait scoring, the qualitative difference in the students' approach to the writing task could be shown in the following ways:

Audience and purpose: In relation to the communicative purpose and the communicative target;

Details: What communicative messages (information) they had chosen for the pamphlet;

Organization: What communicative messages they wanted to convey at the beginning and the end of the passage, and how the messages were structured.

\section{Analysis and results}

\subsection{Qualitative difference in pre-writing and post-writing}

At the pretest writing, 23 kinds of messages have been summarized and 8 categories were sorted. One of the students has not taken the posttest. Therefore, the researchers examined the writings of 37 students at last. Among the 23 kinds of messages of the pretest writing, 20 items of them could be found in the posttest writing. The students had not chosen messages of "H", "J" and "P". Except category IV, the same categories could be sorted in the posttest writing (see table 1). A number of phenomena could be observed in the analysis of the students' writings. The findings were summarized as follows:

On the whole, the students have constructed the communicative messages in different ways though they have chosen similar communicative messages for writing their pamphlets. For each student, difference of communicative messages being conveyed could be found between his/her pretest and posttest writing.

Around $69 \%$ of the students have chosen a Primary 2 student as their communicative target in both pretest and posttest writing. About $65 \%$ students have not changed their communicative target in the posttest. However, about $58 \%$ among them conveyed different communicative messages at the beginning of their posttest writing. About $67 \%$ conveyed various communicative messages at the last paragraph of their posttest. About 35\% students have changed their communicative targets in the posttest. Among them, about 46\% modified their communicative messages at the beginning and about $62 \%$ altered their communicative messages at the last of their posttest writing. Among all the students, about 54\% modified their communicative messages at the beginning and about 65\% altered their communicative messages at the last of their posttest writing (see table 2).

When the communicative messages of the students' writing were sorted, it was found that $38 \%$ among all of them modified the category of content at the beginning and about $49 \%$ changed the category of content at the last of their posttest writing. Regarding to the students who have the same communicative target in the posttest, about $42 \%$ changed the category at the beginning of their posttest writing. 50\% had a different category at the last paragraph of their posttest. Regarding to the students who have changed their communicative targets in the posttest, about $31 \%$ altered the category at the beginning and about $46 \%$ had various categories at the last of their posttest writing (see table 3 ). In short, the students had shown qualitative difference in their post-writing after the intervention.

The above findings suggested that there was a qualitative difference in choosing communicative messages between the students' pretest and posttest writing. The difference showed evidence that they tended to change their approach to tackle the challenge stated in the writing task. After the intervention, every student added or deleted some communicative messages for the posttest writing. They also reconstructed the structure of the writing content whether they have chosen another communicative target. Around half of the students tried to convey various communicative messages at the beginning and the last of their writing in the posttest. When the communicative messages were sorted into different categories, it was found that around 30\% and 50\% of them changed the categories at the beginning and the last of their writing. This might indicate that the students perceived and understood the writing task in different ways after the intervention. Some of them might become aware of the objects of learning, i.e. different communicative approach and messages with clear and definite communicative purpose should be used for different targets. As the National Assessment Governing Board (1998) stated, awareness of the "purpose of a specific writing task affects the ideas that are included, the way in which they are organized, and the manner in which they are expressed" (pp.7-8). If time permitted, further study by other means such as interview should be conducted in order to find out why and how the students had this change. 


\subsection{Subjects' Chinese communicative writing performance with reference to NAEP's writing assessment}

With reference to the primary trait scoring of NAEP's writing assessment, the students had shown improvement in the traits of "audience and purpose", "details", and "organization" with 39\%, 22\% and 16\% gains respectively (see table 4).

\subsubsection{Audience and purpose}

With reference to the messages and categories shown in table 1, it was comparatively reasonable that the students would had a broad introduction of whale or a brief introduction of their role at the beginning of their writing in order to meet the demands of the writing task. It could draw the attention of the tourist, their communicative target, on what they were going to introduce. It met the demands of the advanced achievement level of the trait of "audience and purpose" in the $4^{\text {th }}$ grade of the NAEP as it showed "clear understanding of the writing task and the expected audience" (Barone \& Taylor, 2007, p.20).

At the end of their writing, it would also better to state their communicative purpose further by means of some kinds of interaction such as asking the communicative target to protect the whale or invite him/her to come again. It showed "evidence of ability to engage audience" which was considered as the advanced achievement level of the trait of "audience and purpose" in the $12^{\text {th }}$ grade of the NAEP (Barone $\&$ Taylor, 2007, p.20). Comments on the whale would also be considered to be logical ending as it might arouse the communicative target's interest.

At the pretest writing, about $37 \%$ of the students had a holistic introduction of whale while about $23 \%$ of them had a self-introduction of their role at the beginning. It seemed that more than half of the students had a clear communicative purpose. At the posttest, about $57 \%$ of the students had a holistic introduction of whale while about $11 \%$ of them had a self-introduction of their role (see table 5). The total percentage might suggest that more students had a clear communicative purpose at the beginning of their posttest writing.

At the end of their pretest writing, about $40 \%$ of them focused again on their communicative purpose. About $32 \%$ of them conveyed the idea of respecting the subsistence of whale. $3 \%$ of them invited the communicative target to come again. About $5 \%$ of them made a comment on the whale. However, nearly $60 \%$ of them just continued to describe the different aspects of the whale without any indication of asking for the interaction with their communicative target. Moreover, the second frequent message expressed by the students (18\% of them) was the description of the phenomenon of "whale's spouting "water" (air)" at the end of their writing. It seemed to be not made sense. At the posttest, about $81 \%$ of them focused again on their communicative purpose. The percentage was much higher than the one of the pretest writing. About $67 \%$ of them conveyed the idea of respecting the subsistence of whale. $3 \%$ of them invited the communicative target to come again. About $11 \%$ of them made a comment on the whale. The most frequent message expressed by the students ( $59 \%$ of them) was asking the communicative target to protect the whale (see table 6 ). The result might suggest that the students had understood the critical relationship between communicative purpose and communicative messages.

"Phenomenographic research seeks to describe the major features of the different ways a group of people relate to a phenomenon. This analysis necessarily includes some input from the researchers and is feasible only by examining data from a number of individuals, not just one" (Bowden, 1994, p.14). The pre-writing of each student would be further examined one by one in particular to explore whether they could show communicative purpose and sense of communicative target at both the beginning and the end of their writing. It was found that $27 \%$ of them were able to do so. However, $35 \%$ of them showed them at the beginning only while $14 \%$ showed them at the end only. Furthermore, $24 \%$ did not show clear communicative purpose and sense of communicative target at both the beginning and the end. The post-writing showed improvement in this aspect. It was found that about $57 \%$ of students were able to show communicative purpose and sense of communicative target at both the beginning and the end of their post-writing. It was $30 \%$ more than the pre-writing. Furthermore, about $11 \%$ of them could not show clear communicative purpose and sense of audience at both the beginning and the end. It was $13 \%$ less than the pre-writing (see table $4 \& 7$ ). Thus, the extent of enhancement in the students' awareness of communicative purpose relative to communicative target and communicative messages could be discerned.

\subsubsection{Details}

For the trait scoring of "details" of the NAEP, details and elaboration were examined to see whether they could support the main idea. Similarly, the communicative messages of the students' writing were explored to see whether they were developed around the theme. At the pre-test, most of the students had put a lot of information in their writing, i.e. the pamphlet. It might be owing to the fact that they had just copied the information given by the teacher. Thus, two criteria should be considered. First of all, they had shown the communicative purpose either at the beginning or the end of their writing. Secondly, the messages embedded in their writing could reinforce their communicative purpose. The finding suggested that about $51 \%$ of the students had given adequate details supporting the main idea in their pre-writing. However, the messages conveyed by the students seemed to have no relation to the communicative target that they had chosen. The analysis of the students' post-writing suggested that they became more aware of the critical features of 
communicative purpose and communicative messages. About $73 \%$ of the students had shown the communicative purpose either at the beginning or the end in their post-writing. At the same time, they were able to use suitable communicative messages in the body of their writing in order to reinforce their communicative purpose. It was $22 \%$ more than their pre-writing (see table 4). The findings suggested that their discernment of the critical features, the content of communicative messages should be relative to the communicative purpose and communicative target, has been enhanced.

However, the communicative messages conveyed by the students still had no relation to the communicative target that they had chosen. The students seemed to be unable to discern the critical relationship between the communicative target and communicative messages. With reference to video-taping of the lessons, the discourse among the teacher and students was analyzed. It was found that the students' focal awareness was directed to the relationship between communicative purpose and communicative messages rather than among them and communicative target. Besides, their focal awareness of the critical features was sometimes distracted during the learning process. Thus, the critical feature of communicative target was not given adequate emphasis when the students were doing the learning tasks. In short, the reason might be that the students' focal awareness of the intended object of learning was distracted during the intervention. It might be one of the reasons that the students neglected the critical feature of communicative target in their post writing. The following scripts showed the examples that the teacher distracted the students' focal awareness of the intended object of learning.

Script (1)

[Disc 1/00:48-01:40/Introduction of learning objectives]

T: Can anyone explain to me what the "communicative writing" is?

S1: It can express the meaning of writing to the reader.

T: That is the meaning. Any other classmates?

S1: The writer can have more understanding of the meaning of his/her own writing.

T: Thanks! The most important thing is that you can convey your messages through your writing.

At the beginning of the lesson, the teachers asked the students to explain the meaning of "communicative writing". The student (S1) responded, "It can express the meaning of writing to the reader." She mentioned the critical features of "messages" and "reader". However, when the teacher tried to ask another student, the student (S1) revised her definition that "communicative writing" allowed the writer to further understand the meaning of his/her own writing. Her focal awareness was changed from "reader" to "writer". Finally, the teacher concluded, "The most important thing is that you can convey your messages through your writing". It seemed that the students" attention was directed to the critical feature of communicative messages whereas the communicative target (reader) and the communicative purpose might be overlooked. As Tsui (2003) said, discourse was a process in which meanings were negotiated and common grounds were established. The discourse between the teacher and the student (S1) seemed to establish a common ground that "communicative writing" was mainly concerned with the messages only. This became the shared meaning among the students and her. It might affect what and how the students learned in the following parts of the lessons.

\section{Script (2)}

[Disc 1/02:30-02:52/Introduction of Task 1]

T: Pay attention to the following point. When your classmate asks for a change of coins, you should pay attention to the content he/she say as well as his/her facial expression and the intonation."

(Students were going to complete the task)

[Disc 1/14:20-19:22/Conclusion of Task 1]

T: The purpose of the learning task was to help you to choose suitable content and intonation in match with the communicative target when writing and speaking. Why should we do so? How the learning task helps you in your writing?

(The teacher gave the students one minute for thinking.)

S2: I think we should choose different subject matters when we deal with different purpose and audience.

T: Different matters, i.e. when dealing with different audience, what should we do in choosing subject matters?

S2: Choose suitable vocabularies to describe.

T: "Choose suitable vocabularies to describe". What's the meaning?

S2: Just like molding a character.

T: Molding a character? But I would like to convey the message to the audience. 
(S2 could not answer further.)

\section{S3: The same answer to S2's.}

T: I want to convey the message to a particular audience. If I can analysis the content I am going to speak to him/her, to which procedure will be helpful?

(The students had no response.)

T: Suppose I'm writing to S4, why should I pay attention to the content and ways of expression?

S4: Because it can give S4 a good impression.

T: Giving a good impression. Any more?

S5: The reader will understand the content.

$\mathrm{T}$ : Why will the reader understand the content?

S5: If we write the reasons clearly...like the former example. There might be no need to give reasons to the younger person. If the person is an adult, he/she may want to know the reasons so that they can find out whether we, primary students, use the money in a suitable way.

T: Because of different person...the speaking content...you know the particular audience...you understand him/her...if you choose suitable content, he/she read...he/she can receive your message easier. Just like you spoke to the child. You did not tell him the reason for asking a change of coins. You just spoke to him in gentle way. He would give you a change. When you asked a teacher or a ferocious stranger for a change of coins, they would ask you the reasons. Do you understand? Thus, if you choose different content in match with difference target, other can understand your writing easily. "Communicative writing" means to convey the communicative messages in more effective ways.

Regarding to the above script, the students were asked to pay attention to the content, facial expression and the intonation after understanding the communicative purpose. The emphasis on the content might help them realize the importance of communicative messages. However, the mention of "facial expression and the intonation" might distract the students' awareness of the intended object of learning at the same time. Furthermore, the students might tend to ignore the critical feature of the communicative target when they were doing the learning task. The importance of both content and intonation was restated in the conclusion of the learning objective as the teacher said "the purpose of the learning task was to help them to choose suitable content and intonation in match with the communicative target when writing and speaking." Nevertheless, it could be found that she had already tried to direct the students' focal awareness to communicative target. It might be further exemplified by the response of the student (S2). When she asked the students how the learning task 1 could help them in their writing, the student (S2) thought that they "should choose different subject matters" when they "deal with different purpose and audience." The student (S2) had already extracted the critical features of "different subject matters" as well as "different purpose and audience". However, when the teacher asked the student (S2) what they should do in choosing subject matters in accordance with different audience, she (S2) became hesitated. Then she gave the answer of "choosing suitable vocabularies to describe". The students seemed to be distracted from the object of learning again. Thus, the teacher tried very hard to redirect the students' attention to the object of learning. For example, she used the examples to illustrate that they should choose suitable content for a particular audience so that the latter could receive the communicative messages easily. Nevertheless, she ended the conversation by saying that "communicative writing means to convey the communicative messages in more effective ways". It was very much kept in the ground of the students" awareness again that "communicative writing" was mainly concerned with the communicative messages only.

Besides the distraction from the intended object of learning during the intervention, other reasons might be suggested for the students being unable to discern the critical relationship between the communicative target and communicative messages as follows:

With the influence of past learning experience of writing exposition, the students might think that their writing should include a brief introduction as well as detailed descriptions of appearance, biological structure and habitual behaviors of whale.

Owing to insufficient daily experience, the students might lack the knowledge of the background information of their communicative targets such as a teacher who taught the subject of history, a biologist and a green sweater worker. They might not have any ideas of what communicative messages were suitable for these communicative targets. This might be proved by the fact that about $69 \%$ of them chose a Primary 2 student as their communicative target in both pretest and posttest writing.

The provision of a large piece of information for the students to choose for their writing might not help them. Some of them might not have enough time to read all information. Some of them might just copy it directly without further thinking. Adverse effects might happen. 
The writing of a pamphlet in the pretest and posttest might not induce a strong sense of communicative target to the subjects. Writing a letter without too much information provided might be more effective in urging their needs to consider and choose appropriate communicative messages in match with the communicative target.

\subsubsection{Organization}

With regards to the trait scoring of "organization" of the NAEP, the communicative messages in the students' writing should be noticeably organized with clearly marked beginning and ending in accordance to the communicative purpose. When analyzing their writing, the priority would be that they had shown their awareness of the "audience and purpose" at both the beginning and the ending of their writing as well as given "evidence of ability to engage audience". Afterwards, the communicative messages in the body of their writing should be constructed in a logical sequence. At the pretest, about $11 \%$ of the students could achieve the desired level of "organization". Most of them were unable to show clearly marked beginning and ending in their writing. Some of them repeated the same category of content in a discrete order. Some had "a holistic introduction of whale" in the middle of their writing. At the posttest, about $27 \%$ of them clearly organized the communicative messages with noticeably marked beginning and ending in match with the communicative purpose. It was $16 \%$ more than the pre-writing (see table 4). It seemed that they had more focus of their writing. In the pretest writing, comparatively various kinds of communicative messages offered by different students. However, in the posttest, more students tended to stated "whale is a mammal" at the beginning of their writing and ended their passages with the communicative message of protecting the whale. It seemed that they would like to have a broad introduction of the main role, the whale, at the beginning. Then they provided considerable information such as biological structure and habitual characters of the whale in order to portray its unique and valuable features. Thus, it was reasonable that they asked the readers to protect the whale at the end of their writing. The students tended to give a number of information about the whale only in the pretest while they had clearer purpose of writing in the posttest. The theme of their posttest writing seemed to be "the whale is precious and so we have to protect them". The communicative messages were organized in consistency of the theme. In other words, they have discerned the critical features of communicate messages relative to communicative purpose and communicative target.

Regarding to the structure of content, the pattern of categories displayed in the students' pre-writing could not be observed as the communicative messages were conveyed in various orders. It seemed that the students tended to give a number of information about the whale only. However, the pattern of categories displayed in the students' post-writing showed their capability of Chinese communicative writing by discerning critical features of the communicative purpose, communicative targets and communicative messages. Regarding to the structure of content, four noteworthy patterns could be found in the students' posttest writing as below:

Pattern 1: Holistic introduction of whale (I) $\rightarrow$

Appearance \& biological structure of whale (II) $\rightarrow$

Habitual behavior of whale (III) $\rightarrow$

Whale's subsistence (V)

Pattern 2: Appearance \& biological structure of whale (II) $\rightarrow$

Habitual behavior of whale (III) $\rightarrow$

Whale's subsistence (V)

Pattern 3: Whale's subsistence (V) $\rightarrow$

Holistic introduction of whale (I) or/and Appearance \& biological structure of whale (II) or/and Habitual behavior of whale (III) $\rightarrow$

Whale's subsistence $(\mathrm{V})$

Pattern 4: Writer's self-introduction (VI) $\rightarrow$

Holistic introduction of whale (I) or/and Appearance \& biological structure of whale (II)

$\rightarrow$ Whale's subsistence (V)

Compared to the structures displayed in the pretest writing, the patterns of categories being constructed in the students' posttest writing seemed to have clearer purpose. In their posttest writing, increased numbers of students tended to construct their passage with the pattern of "other categories" introducing the information of the whale plus Category V ("Whale's subsistence). No matter what pattern they used, most of them choose Category V for the ending of their writing. It seemed that they wanted to arouse the communicative target' concern of the whale's right of subsistence. It seemed that the development of structure in the students' posttest writing was more logical with a clear communicative purpose. Among the above patterns, Pattern 1 (about 24\%) was the most frequently displayed in the students' posttest writing. The result might further conclude that the students had discerned the relation of two critical features, i.e. 
"communicative purpose" and "communicative messages" of writing. In other words, their capability of Chinese communicative writing had enhanced.

\section{Discussion and suggestions}

This empirical study demonstrated a valuable experience of applying the variation theory to teach Chinese communicative writing. The introduction of the patterns of variation and invariance in the object of learning did influence how the students understand it. Qualitative change could be observed after the intervention. Though being within such a short period (a double lesson) of intervention, the students showed their awareness of the critical features of the object of learning. When noticing communicative purpose, communicative target and communicative messages simultaneously, the students experienced the relation between them in a new way and acted accordingly. As Runesson (2006) said, "taking the object of learning into consideration is important from the point of view of pedagogy and for enhancing student learning" (p.406). The result of this study shed a new light on reducing the problem of students' writing in monotonous ways and lack of focus in the future.

Exploring the lived experience of students in this study opened up questions about the pedagogy of writing and about the desirable outcomes of such teaching from the perspective of students. It reiterated the importance of regarding students as a "true writer". Teachers should not be the only audience of their writing. Various learning context and tasks with diverse purposes or audiences should be provided in students' writing training so that their communicative awareness can be fostered. Chinese communicative writing should be explicitly taught to students. As there are a number of critical components of Chinese communicative writing, many dimensions of variation can be opened for students to experience and understand. The question is which components of Chinese communicative writing should be opened as the dimensions of the object of learning in accordance with students' age or their writing development. To solve this problem, variation theory can be applied in order to investigate the significance of variation for possibilities of learning through 'learning study', as suggested by Runesson (2006). A group of teacher can work together to solve a well known problem of a teaching topic by means of an action research. Students will be tested after each lesson in order to find out their achieved level of the topic. With reference to these data, teachers can discuss and plan their lessons with a focus of expected learning outcome. Moreover, each lesson will be video recorded for the teachers to study and discuss immediately. Together with the test results, they can plan or revise another lesson in a more effective way (Lo, Marton, Pang \& Pong, 2004; Runesson, 2006). As Holmquvist, Gustavsson and Wernberg (2007) stated, it was difficult for teachers to see how their teaching affected students' future learning though their interests in learning was obvious. The "learning study" might be helpful.

The study demonstrated the mismatch between the intended outcome (intended object of learning) and observed outcome (lived object of learning). Students were expected to convey different communicative messages in accordance to various communicative targets. However, their post-writing showed that they were not aware of this relation. The previous analysis of the lesson enactment suggested the reasons. The teacher unconsciously distracted the students' focal awareness of the intended object of learning or placed too much emphasis on communicative messages during the lesson. The result restated the impact of teacher's questioning and feedback on students' learning. As Godinho and Wilson (2006) pointed out, "questions should always be purpose driven" (p.4). Whatever types the questions are, they should always be used for directed students' focal awareness of the intended object of learning. According to the variation theory, to learn means to experience. Questions play a critical role in students' learning as they help them make sense of the world (Godinho \& Wilson, 2006). However, questions cannot function without constructive feedback. Effective questioning followed by constructive feedback can facilitate and enhance students' learning. Questioning and feedback are popular technique in each classroom teaching everyday but their effective use is still under questions. In short, teachers need to pay more concerns to equip themselves with these skills.

Finally, this is a preliminary study and the program needs to be tailored for future use. As this study is school-based with a limited number of research subjects, the results will be valid for the target group only. Moreover, students' performance might be different from the way they usually act if they are treated as "research subjects" (Bogdan \& Biklen, 1998). Further research is needed using other research methods to clarify students' ideas.

\section{Conclusion}

This study attempted to apply the variation theory to teach Chinese communicative writing. It aimed at exhibiting the students' capability of experiencing the phenomena in different ways and so showed qualitative difference in their approach to writing. 38 students in a Primary 5 class took part in the study. A double-lesson was used to implement the intervention. Three learning tasks were designed and systematically structured to help to facilitate students' discernment of the critical features of Chinese communicative writing, i.e., the communicative purpose, communicative targets and communicative messages. A pattern of variation and invariance that serves the function of "separation" or "fusion" was developed to show students that different communicative approach and messages with clear and definite purpose will be used for different communicative targets; first to have students discuss and define the communicative purpose of tasks, and express the different lines of thinking in accordance with the difference in the communicative targets of 
communication; then to discuss the background information of different communicative targets and the importance of selecting communicative messages relevant for them. A comparison between students' writings before and after the study revealed qualitative difference in their writings. In the post-study writing, students showed clearer communicative purpose. The pattern of variation and invariance that functioned as "separation" and "fusion" was thus shown to be highly invaluable to the teaching of Chinese communicative writing. In conclusion, this study supports theoretical research on employing the variation theory to teach Chinese communicative writing.

\section{References}

Barone, D. \& Talyor, J.M. (2007). The practical guide to classroom literacy assessment. Thousand Oaks: Corwin Press.

Bogdan, R.C. \& Biklen, S.K. (1998). Qualitative research for education. An introduction to theory and method. Boston: Allyn and Bacon.

Bowden, J.A. (1994). Experience of phenomenographic research. In J.A.Bowden and E. Walsh (Eds.). Phenomenographic research: variation in method. The Warbuton Symposium (pp.43-55). Melbourne: Royal Melbourne Institute of Technology.

Bowden, J.A. (1994). The nature of phenomenographic research. In J.A.Bowden and E. Walsh (Eds.). Phenomenographic research: variation in method. The Warbuton Symposium (pp.1-16). Melbourne: Royal Melbourne Institute of Technology.

Godinho, S. \& Wilson, J. (2006). How to succeed with questioning. Carlton South Vic: Curriculum Corporation.

Grabe, W. \& Kaplan, R.B. (1996). Theory \& practice of writing. Harlow: Pearson Education Limited.

Holmqvist, M., Gustavsson, L and Wernberg, A. (2007). Generative learning: learning beyond the learning situation. Educational Action Research, 15(2), 181-208.

Lo, M.L., Marton, F., Pang, M.F. \& Pong, W.Y. (2004). Toward a pedagogy of learning. In F. Marton and A.B.M. Tsui (Eds.), Classroom discourse and the space of learning (pp.189-226). New Jersey: Lawrence Erlbaum Associates, Publishers.

Marton, F. and Booth, S. (1997). Learning and awareness. New Jersey: Lawrence Erlbaum Associates, Publishers.

Marton, F., Runesson, U. \& Tsui, A.B.M. (2004). The space of learning. In F. Marton and A.B.M. Tsui (Eds.),

Classroom discourse and the space of learning (pp.3-42). New Jersey: Lawrence Erlbaum Associates, Publishers.

The National Assessment Governing Board (1998). Writing framework and specifications for the 1998 National Assessment of Educational Progress. Washington, DC: The National Assessment Governing Board.

Prosser, M. (1994). Some experience of using phenomenographic research methodology in context of research in teaching and learning. In J.A.Bowden and E. Walsh (Eds.). Phenomenographic research: variation in method. The Warbuton Symposium (pp.31-42). Melbourne: Royal Melbourne Institute of Technology.

Runesson, U. (2006). What is it possible to learn? On variation as a necessary condition for learning. Scandinavian Journal of Educational Research, 50(4), 397-410.

Tse, S.K. (2002). Writing abilities and checklist for teaching Chinese writing. In S.K. Tse and M.S.K. Shum (Eds.). Using diagnostic checklist to teach Chinese writing (pp.31-44) (Text in Chinese). Hong Kong: Hong Kong University Press.

Tsui, A.B.M. (2003). The shared space of learning. In F. Marton and A.B.M. Tsui (Eds.), Classroom discourse and the space of learning (pp.165-186). New Jersey: Lawrence Erlbaum Associates, Publishers.

Wolcott, W. \& Legg, S.M. (1998). An overview of writing assessment. Illinois: National Council of Teachers of English. 
Table 1. Coding of messages and sorted categories in the students' writing

\begin{tabular}{|c|c|c|c|}
\hline Code & Categories & Code & Messages \\
\hline \multirow[t]{3}{*}{$\mathrm{I}$} & \multirow{3}{*}{$\begin{array}{l}\text { Holistic introduction } \\
\text { of whale }\end{array}$} & $\mathrm{A}$ & Whale is a mammal \\
\hline & & $\mathrm{B}$ & Types of whale/the biggest \& smallest whale \\
\hline & & $\mathrm{C}$ & Whale is an ancient animal \\
\hline \multirow[t]{6}{*}{ II } & \multirow{6}{*}{$\begin{array}{l}\text { Appearance \& } \\
\text { biological structure } \\
\text { of whale }\end{array}$} & $\mathrm{D}$ & Appearance \& size of whale \\
\hline & & $\mathrm{E}$ & Description of whale's brain \\
\hline & & $\mathrm{F}$ & Description of whale's eyes \\
\hline & & G & Description of whale's communication organs \\
\hline & & $\mathrm{H}$ & Description of whale's teeth \\
\hline & & I & Description of whale's stomachs \\
\hline \multirow[t]{6}{*}{ III } & \multirow{6}{*}{$\begin{array}{l}\text { Habitual behavior of } \\
\text { whale }\end{array}$} & $\mathrm{J}$ & Whale's collective nature in daily living \\
\hline & & $\mathrm{K}$ & Food of whale \\
\hline & & $\mathrm{L}$ & $\begin{array}{l}\text { Whale's periodical long journey between the south } \\
\text { latitude and the north latitude }\end{array}$ \\
\hline & & $\mathrm{M}$ & Whale's diving \\
\hline & & $\mathrm{N}$ & Whale's spouting "water" (air) \\
\hline & & $\mathrm{O}$ & Spread of whale \\
\hline IV & Whale's character & $\mathrm{P}$ & Whale's character \\
\hline \multirow[t]{4}{*}{$\mathrm{V}$} & \multirow[t]{4}{*}{ Whale's subsistence } & Q & Whale's "suicide" \\
\hline & & $\mathrm{R}$ & Whale's being hunt/death/right of existence \\
\hline & & $\mathrm{S}$ & Organization working for protecting whale \\
\hline & & $\mathrm{T}$ & Asking the readers to protect the whale \\
\hline VI & $\begin{array}{l}\text { Writer's } \\
\text { self-introduction }\end{array}$ & $\mathrm{U}$ & Writer's self-introduction \\
\hline VII & $\begin{array}{l}\text { Inviting customers to } \\
\text { come again }\end{array}$ & $\mathrm{V}$ & Inviting customers to come again \\
\hline VIII & Comments on whale & W & $\begin{array}{l}\text { Whale being lovely/being worth studying/having a lot } \\
\text { of characteristics }\end{array}$ \\
\hline
\end{tabular}


Table 2. Percentage of the students who had chosen to write for the same or a different message for the same or a different target in the post-writing

\begin{tabular}{|c|c|c|c|}
\hline & $\begin{array}{l}\text { Total students } \\
(\mathrm{n}=37 ; 100 \%)\end{array}$ & $\begin{array}{l}\text { The same writing } \\
\text { target }(n=24 ; 65 \%)\end{array}$ & $\begin{array}{l}\text { Different writing target } \\
(\mathrm{n}=13 ; 35 \%)\end{array}$ \\
\hline $\begin{array}{l}\text { Same message at the } \\
\text { beginning }\end{array}$ & About $46 \%$ & About $42 \%$ & About 54\% \\
\hline $\begin{array}{l}\text { Different message at } \\
\text { the beginning }\end{array}$ & About 54\% & About 58\% & About $46 \%$ \\
\hline Total: & $100 \%$ & $100 \%$ & $100 \%$ \\
\hline $\begin{array}{l}\text { Same message at the } \\
\text { last }\end{array}$ & About $35 \%$ & About 33\% & About 38\% \\
\hline $\begin{array}{l}\text { Different message at } \\
\text { the last }\end{array}$ & About 65\% & About $67 \%$ & About $62 \%$ \\
\hline Total: & $100 \%$ & $100 \%$ & $100 \%$ \\
\hline
\end{tabular}

Table 3. Percentage of the students who had chosen to write for the same or a different category for the same or a different target in the post-writing

\begin{tabular}{|c|c|c|c|}
\hline & $\begin{array}{l}\text { Total students } \\
(\mathrm{n}=37 ; 100 \%)\end{array}$ & $\begin{array}{l}\text { The same writing } \\
\text { target }(n=24 ; 65 \%)\end{array}$ & $\begin{array}{l}\text { Different writing target } \\
(\mathrm{n}=13 ; 35 \%)\end{array}$ \\
\hline $\begin{array}{l}\text { Same category at the } \\
\text { beginning }\end{array}$ & About $62 \%$ & About 58\% & About 69\% \\
\hline $\begin{array}{l}\text { Different category at } \\
\text { the beginning }\end{array}$ & About 38\% & About $42 \%$ & About 31\% \\
\hline Total: & $100 \%$ & $100 \%$ & $100 \%$ \\
\hline $\begin{array}{l}\text { Same category at the } \\
\text { last }\end{array}$ & About 51\% & About 50\% & About 54\% \\
\hline $\begin{array}{l}\text { Different category at } \\
\text { the last }\end{array}$ & About 49\% & About 50\% & About $46 \%$ \\
\hline Total: & $100 \%$ & $100 \%$ & $100 \%$ \\
\hline
\end{tabular}


Table 4. Percentages of the students who had shown improvement in their Post-writing

\begin{tabular}{|c|c|c|c|c|}
\hline Traits & Achievement & $\begin{array}{l}\text { Pre-writing } \\
(\mathrm{n}=37)\end{array}$ & $\begin{array}{l}\text { Post-writing } \\
(\mathrm{n}=37)\end{array}$ & Gains \\
\hline $\begin{array}{l}\text { Audience and } \\
\text { purpose }\end{array}$ & $\begin{array}{l}\text { Showing communicative purpose and sense } \\
\text { of communicative target at both beginning } \\
\text { and ending }\end{array}$ & About $27 \%$ & About $57 \%$ & $39 \%$ \\
\hline Details & $\begin{array}{l}\text { Showing communicative purpose either at } \\
\text { beginning or ending with the support of } \\
\text { embedded messages in the body }\end{array}$ & About $51 \%$ & About $73 \%$ & $22 \%$ \\
\hline Organization & $\begin{array}{l}\text { Showing noticeable organization of } \\
\text { communicative messages with clearly } \\
\text { marked beginning and ending relative to } \\
\text { communicative purpose }\end{array}$ & About $11 \%$ & About 27\% & $16 \%$ \\
\hline
\end{tabular}

Table 5. Messages and categories conveyed at the beginning of the students' pre-writing and post-writing

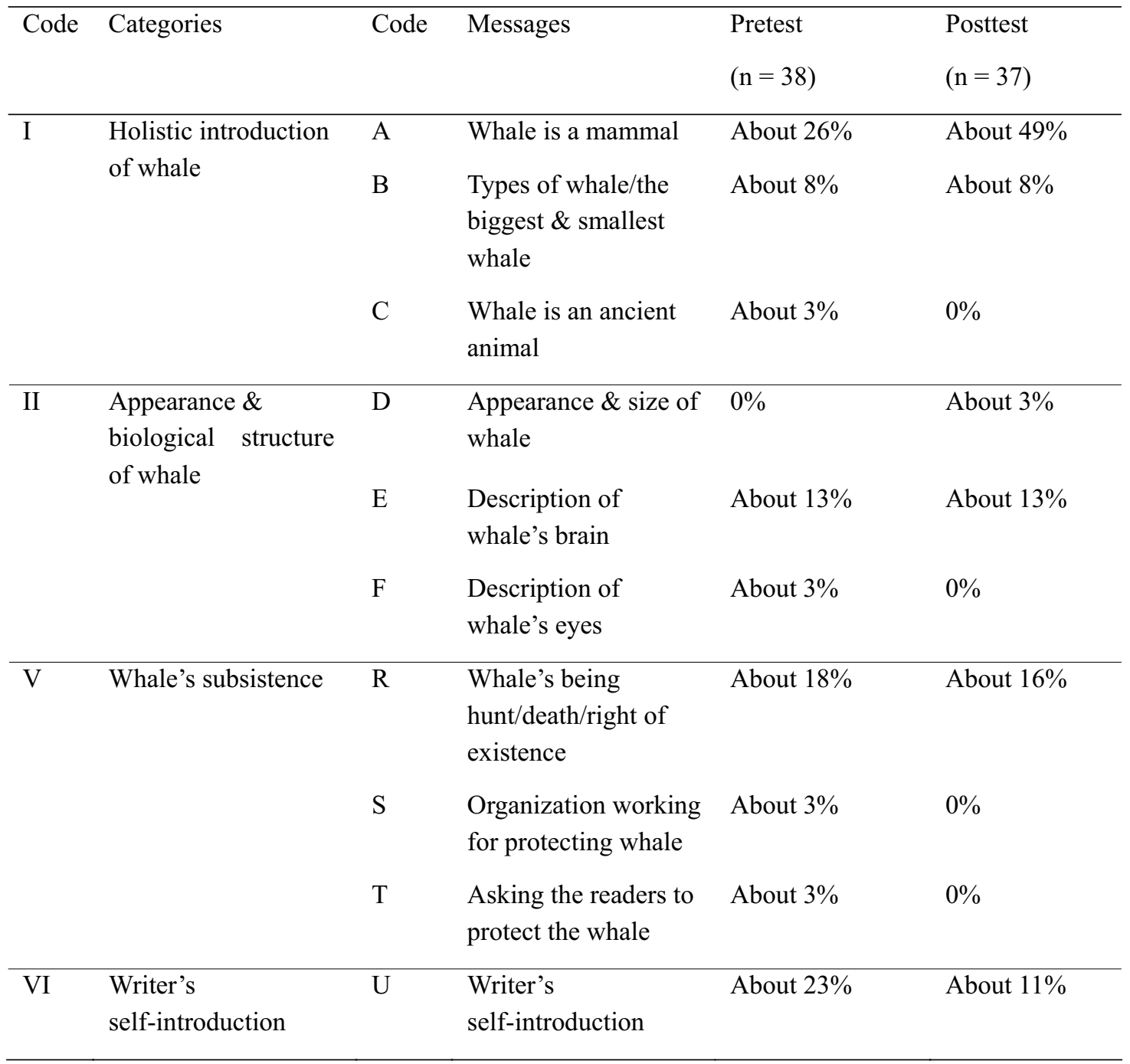


Table 6. Messages and categories conveyed at the end of the students' pre-writing and post-writing

\begin{tabular}{|c|c|c|c|c|c|}
\hline Code & Categories & Code & Messages & $\begin{array}{l}\text { Pretest } \\
(\mathrm{n}=38)\end{array}$ & $\begin{array}{l}\text { Posttest } \\
(\mathrm{n}=37)\end{array}$ \\
\hline \multirow[t]{2}{*}{ II } & \multirow{2}{*}{$\begin{array}{l}\text { Appearance \& } \\
\text { biological structure } \\
\text { of whale }\end{array}$} & $\mathrm{F}$ & $\begin{array}{l}\text { Description of } \\
\text { whale's eyes }\end{array}$ & About $8 \%$ & $0 \%$ \\
\hline & & I & $\begin{array}{l}\text { Description of } \\
\text { whale's stomachs }\end{array}$ & About 3\% & About 3\% \\
\hline \multirow[t]{4}{*}{ III } & \multirow{4}{*}{$\begin{array}{l}\text { Habitual behavior of } \\
\text { whale }\end{array}$} & $\mathrm{K}$ & Food of whale & About $13 \%$ & About 3\% \\
\hline & & $\mathrm{L}$ & $\begin{array}{l}\text { Whale's periodical } \\
\text { long journey between } \\
\text { the south latitude and } \\
\text { the north latitude }\end{array}$ & About $13 \%$ & About $5 \%$ \\
\hline & & $\mathrm{N}$ & $\begin{array}{l}\text { Whale's spouting } \\
\text { "water" (air) }\end{array}$ & About $18 \%$ & About $8 \%$ \\
\hline & & $\mathrm{O}$ & Spread of whale & About 5\% & $0 \%$ \\
\hline \multirow[t]{3}{*}{$\mathrm{V}$} & \multirow[t]{3}{*}{ Whale's subsistence } & Q & Whale's "suicide" & About 5\% & About 3\% \\
\hline & & $\mathrm{R}$ & $\begin{array}{l}\text { Whale's being } \\
\text { hunt/death/right of } \\
\text { existence }\end{array}$ & About 3\% & About 5\% \\
\hline & & $\mathrm{T}$ & $\begin{array}{l}\text { Asking the readers to } \\
\text { protect the whale }\end{array}$ & About $24 \%$ & About 59\% \\
\hline VII & $\begin{array}{l}\text { Inviting customers to } \\
\text { come again }\end{array}$ & $\mathrm{V}$ & $\begin{array}{l}\text { Inviting customers to } \\
\text { come again }\end{array}$ & About 3\% & About 3\% \\
\hline VIII & Comments on whale & $\mathrm{W}$ & $\begin{array}{l}\text { Whale being } \\
\text { lovely/being worth } \\
\text { studying/having a lot } \\
\text { of characteristics }\end{array}$ & About $5 \%$ & About 11\% \\
\hline
\end{tabular}


Table 7. Percentages of the students who had shown communicative purpose and sense of audience in their writing

Total students

$$
(\mathrm{n}=37)
$$

Pre-writing Post-writing

Showing communicative purpose and sense of audience at both the beginning and the end

About 27\% About 57\%

Showing communicative purpose and sense of audience at the beginning only

About $35 \% \quad$ About $11 \%$

Showing communicative purpose and sense of audience at the end only

About $14 \% \quad$ About $21 \%$

Not showing clear communicative purpose and sense of audience at both the beginning and the end

About 24\% About $11 \%$

Total $100 \% \quad 100 \%$ 